\title{
Translations, Illustration and Adaptation ${ }^{1}$
}

\begin{abstract}
Alain DÉSOUlières
The author would like to pose some basic questions about three basic notions in this paper and discuss elaborately about the different aspects and the contribution of various individuals in this regard. In the first, the author will be dealing with technical/general translation versus literary translation and contrasting training. The second question the author will be delving into is about whether there exists a clear boundary between literary translation, adaptation and creative writing or not. The up and downs of illustration in literary translation: the case of French, English and Urdu and, more specifically, the case of Urdu as a target language in the late 19th century would be the third question to be dealt within the paper.
\end{abstract}

Keywords: translation, French, English, Urdu, $19^{\text {th }}$ century literary translation, Arabian Nights

From the very beginning I would like to state that the act of translating is both practical and political in which you do fulfil a pressing need for communication between two languages and at the same time you give full autonomous status and recognition to the source language by establishing an equivalence with a recognised official language.

I also would like to quote a famous example of recognition of a language, that is, the creation of the Urdu (and Hindi, actually named Hindustani) chair in my University in 1830 by Garcin de Tassy when the French School of Oriental languages was reluctant to consider the need of studying and teaching Urdu and Hindi literatures and languages. First, the very act of translating a so called non classical and non religious language was considered useless and unworthy and it was said that among languages labelled as 'Oriental', languages such as Hebrew, Arabic, Persian, Turkish and modern Northern Indian languages were not to be considered worth of study (Tamil being the language of then French territories in India, its recognition as a 'useful' colonial language was immediate but as a literary language it was a later fact and only from the moment Tamil literature was translated into French, the official language).

\footnotetext{
${ }^{1}$ The present paper is elaborated from a Plenary Lecture that I presented for Translation and Knowledge Society, A Conference, Workshop \& Translation, 07-09 March 2018, NTM Mysore, but also aggregates some remarks from previous lectures of mine delivered at two training sessions for translators, NTM, CIIL, Mysore.
} 


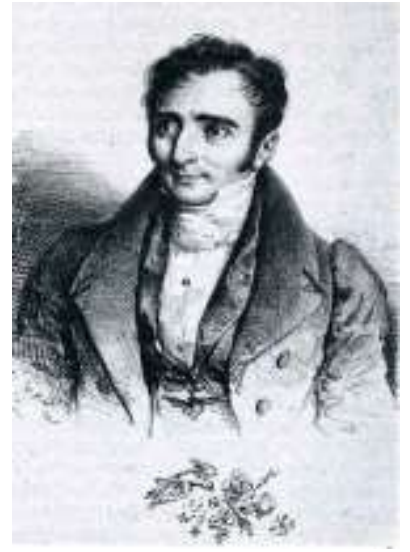

FIGURE 1. Portrait of Garcin de Tassy, first ever professor of Hindustani (mostly Urdu) in Paris Royal School of Oriental Languages, in his younger days. ${ }^{2}$

Garcin de Tassy, the author of manuals of Hindustani Language (183031), neither him nor his successor Deloncle could finish a French Urdu Dictionary while the British scholars did achieve several English Urdu dictionaries. Fortunately, he managed to translate and comment on many Urdu poems and Urdu critical writings, some of which have disappeared in original. Garcin de Tassy continued corresponding in Urdu and translating into French for nearly forty years. He was never allowed to go to India.

Before advocating for the study of Hindustani literature, Garcin de Tassy had learnt some Arabic and Turkish languages, initially to prepare for a commercial career but soon wanted to study and teach literature. He discovered Hindustani through what he first thought was Persian and from some French manuscripts (manuals, glossaries) produced by official interpreters and kept in the French National Library. More precisely, he had seen Aussant's manuscript of manual for interpreters in Hindustani working for the then defunct French East Indies Company and also an anonymous grammar of Hindustani in Portuguese, Gramatica Indostanica (sic), published in Rome in 1777 but actually written in Portuguese by a Jesuit missionary around 1730 in Delhi. ${ }^{3}$ Garcin de Tassy was neither interested by the work of commercial translation and interpreters nor by that of missionary missions. His idea was to give full recognition to Northern modern Indian languages and literature, starting with Urdu and Hindi.

He engaged a campaign through the official government Press (namely Le Moniteur Universel) from 1828 to 1830 in favour of the creation of an

\footnotetext{
${ }^{2}$ Source : INALCO archives and my own publication within the INALCO Bicentenary volume, 1995

${ }^{3}$ My own hypothesis, cf. Gramatica Indostanica, translation and historical introduction, Alain Désoulières, doctoral thesis, 1981, Sorbonne Paris III, I also identified the probable Jesuit author and interpreter.
} 
Hindustani Chair at the young School of Oriental Languages (created in 1795).

However, there was then open hostility against Hindi and Urdu among academics. It was felt that those literatures were not genuine as they were supposed to be mere adaptations and translations of Sanskrit and Persian. That hostility was even reflected in the weekly Parisian scientific journals. It was felt that School of Oriental Languages should devote itself to the development of traders, interpreters, and diplomats because modern Asian language and literature was not genuine (actually the study and translation of classical Arabic, biblical Hebrew, old Sanskrit texts, old Persian, classical Chinese was considered as a must to placate local elites while Europeans were conducting an aggressive trade policy). Furthermore, the French secular Republic also wanted it.

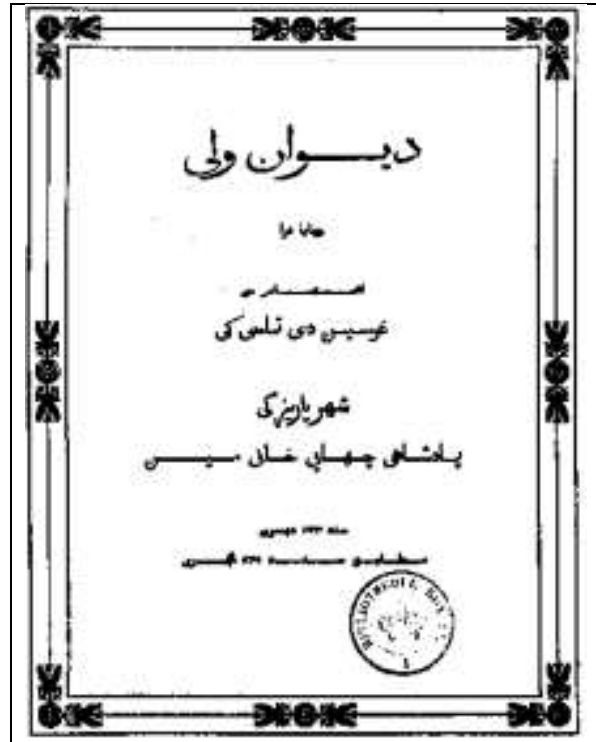

FIGURE 2. Title page of The Divan of Wali(1834 ed.)

\section{Text \\ Diwān [e] Walī \\ chāpā hu'ā ahtamām sī [se] gaārsīn dī tāsī [Garcin de Tassy] \\ śahar [e] pārī kī pādiśāhī chāp̄ì xān̄̄ men [mẽ] sanā 1834 'īsawī mutābiq sanā 1249 hijrī}

The Divan of Wali, printed under supervision of Garcin de Tassy, in the City of Paris at the Royal Printing Press, the year 1834 A.D. corresponding to the year 1249 of the Hijri Era.The seal reads : Bibliothèque Royale / Royal Library.

\section{TABLE 1. Illustration and text from The Divan of Wali}

But quite unexpectedly Garcin de Tassy won the battle and was installed in the Urdu academic chair at the end of 1830, thanks to his secret weapon, a rather well done translation and bilingual edition of the Divan of Wali Dakhani. I say 'a well done work' because G. de Tassy, though he was not fluent in Urdu, had managed a well sounding translation and adaptation to the French taste for Oriental fashion and the taste of the day, with a learned introduction and footnotes about Urdu poetry and conventional clichés. That was perhaps the first ever bilingual publication of an Indian poet outside 
India. So we had a sudden $U$ turn among the academics and they discovered that translation as well as adaptation could be creative and not only informative, that too, in Urdu as well as in French. They also learnt that a French artist could engrave the beautiful Indian Persian calligraphy (nastaliq) without actually knowing Urdu. Therefore, even without special and inadequate typography, image was already a powerful vector. So from that moment, translating modern Indian languages gained literary and scientific recognition in the French academic world as well as in Europe.

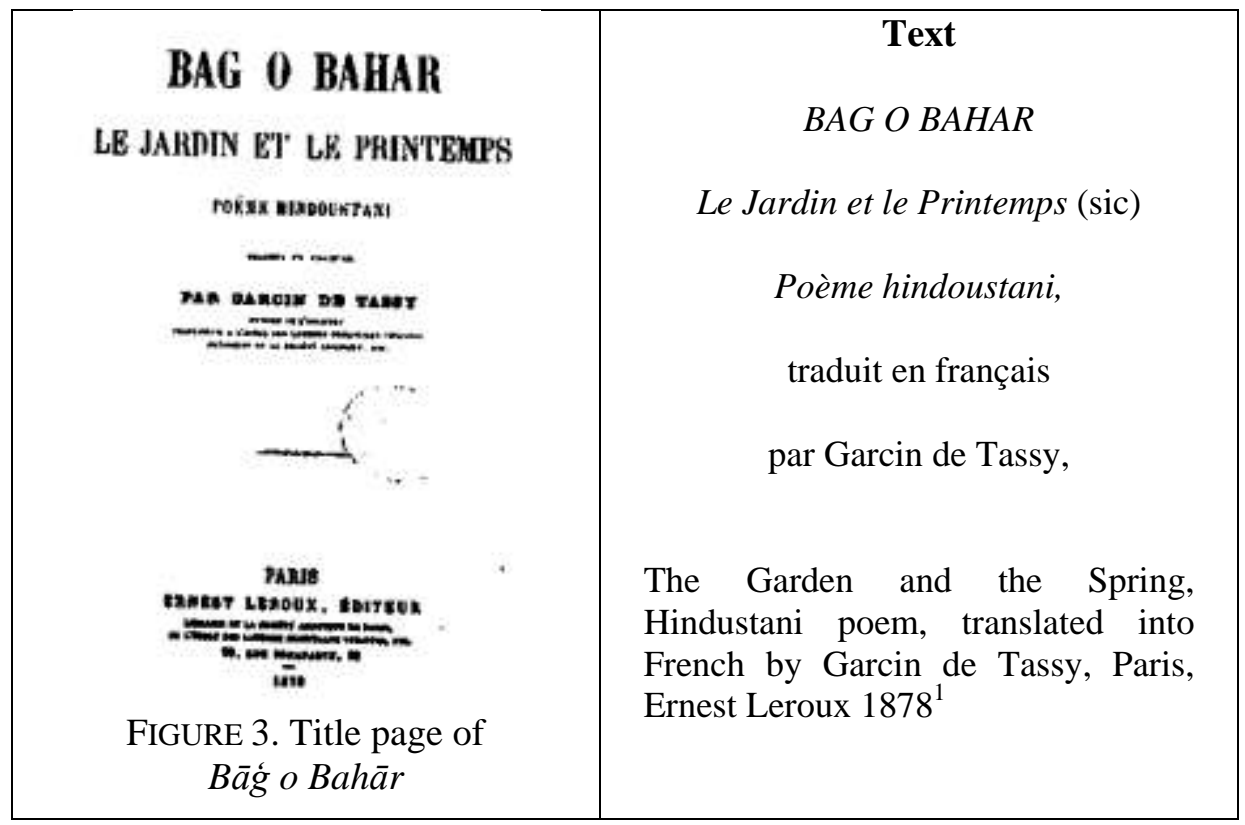

TABLE 2. Illustration and text from the French translation of Bā̀g o Bahār

\section{From Technical to Literary Translation}

Coming to translation of technical works in Indian language into French, the colonial needs were limited but not negligible. Apart from the tiny French territories in India (mostly Tamil speaking) there was also Indian indented labour used by the French in Indochina and in some Indian Ocean Islands and even in French Africa (e.g. Gujarati shopkeepers in Madagascar). These people, many of them had a knowledge of what was Hindustani of those days, were also employed in French Army and colonial police. So having manuals and technical literature (even through English) was considered useful.

Later on, particularly after the colonial era, these people became French citizens (Francophones but also creole speakers) but were very much conscious of their origins and again there was a need for translating modern Indian literature into French. Translation for commercial purposes was not needed anymore. 
What has been said of Hindustani and Tamil related to French translational needs is much more significant and important if we are to consider Arabic language. Without going into details we may say that now literary translation from Arabic into French is very important, (even from Egypt, which was never a French colony). There is now a lasting link between creative writing in French and Arabic that is broader than adaptation and translation.

\section{The New Washing Machine and the New Translating Machine: A True Story}

If I take the example of my brand new washing machine (probably made in China), it has a beautiful technical manual with some pictures and schemes with numbers as explanation keys referring to another part of the booklet with instructions and technical terms in at least twenty seven languages. As a proud European I am flattered, as a non technical French savvy I am puzzled: first the French text is barely understandable (generated by a computer) without clear definition of the latest technical innovations and specific new washing programmes that were so expensive. The English text is somehow better as it is the source language but of no real help as far as those technicalities are concerned, and the situation is worse in Portuguese or Spanish. In addition the tiny pictures and plans and charts are full of enigmatic symbols and numbers that are supposed to be universal.

Of course I could phone to the hot line and after fifteen minutes I would be redirected to the Internet site of the washing machine makers. But suppose my granddaughters are holding my landline phone and playing with my computers ... How I wish I had a plain French booklet nicely translated from technical English by a competent person with some beautiful pictures including simple French explanations. Clearly for technical translation, as well as for literary translation, elegance, that is, aesthetics go hand in hand with lexical precision.

\section{Two Personal Experiments : 1. Translating an Anthology of Urdu Poetry into French}

When I set myself on translating an anthology of Urdu poetry into French I had three aims (as an academic):

(1) First make a literal translation for every poem that could be straight away be compared to the original,

(2) Then compose a literary translation having some music or rhythm and images that would possibly charm the ear and heart of the French reader,

(3) Give a short comment about the author and metrics and introduce footnotes whenever necessary e.g. regarding conventional Urdu clichés and similes, metrics, and poetic conventions. Who says that literary translation may not be technical?

Regarding poetry which is a set of techniques and rules apart of being an artistic medium, you may hide the technicalities and stick with your 
supposedly beautiful result without footnotes or you may opt for a bilingual text and literal translation plus poetic translation plus footnotes and comments, technicality will always be there. I was even more conscious of that when I started collaborating with a French poet who did not know Urdu but would closely check the literary quality of my rendering.

At the end of the translating task and at the moment of publishing I was not allowed to have a bilingual text except for one poem (so most of my calligraphic efforts were lost, in any case there was no room whatsoever for any kind of illustration within the limits of a pocket size collection, said the publisher quoting the printer). Also maintaining a duality of literal versus literary translation was not possible, according to the publisher's constraints except for one poem in the introduction.

Another point is that translating an anthology implied fourteen different authors. Therefore it was difficult to have coherence in style as I was translating mostly an anthology of Urdu ghazals and the publisher's commercial view was to bank on the fame of Urdu ghazal. He had seen translations into English (selling well) but would not risk a big academic volume, rather opting for a small anthology of Urdu ghazals within his popular and affordable pocket collection of translated poetry across the world. Should we have some archaic forms in the target language while translating the oldest poems? Wouldn't that somehow impede the appreciation by the common reader? So we came to a middle approach: my translation should be literary, that is, adopting French metric and versification but as close as possible to the Urdu ghazal. That would mean trying to have between twelve and fourteen syllable regular verses with a rich rhyme at the end of the lines as much as possible, thus getting close to the French sonnet tradition which is still alive and popular, and, on the other hand, writing in 20th Century French anyway.

\section{Two Personal Experiments: 2. Translating Manto's Urdu stories [afsāne] into French}

I undertook translating fifty four Urdu stories into French in 2007-2008. Although I was dealing with a single author and modern Urdu only, I still faced some difficulties when I tried to have an academic work of literary translation as opposed to the commercial project of my publisher. He had a faulty English translation as a model and a very wrong perception of Manto's literary achievements. His choices were dictated by that (incomplete and censured) translation, and he was not aware of the multiple, and sometimes contradicting editions of Manto's works, neither did he know anything about Manto's works as a cinema critic. Along with Manto's life long commitment as a journalist, I felt that these facts should be properly mentioned and commented in a literary introduction, coupled with historical and sociocultural footnotes for the benefit of the French speaking reader, and with some original illustrations like a photo of one of Manto's own two Urdu 
typewriters (in his times no other Urdu writer would use it, he would not hesitate to do so especially for his cinema and radio drama scripts).

But somehow my scholarly work proved too bulky in term of pages. I could not document my introduction on Manto life and literary carrier although I had secured some original documents and photographs with the permission of the author's family. Further, because I was translating complete and verified stories (confronting different versions of the same story), contrary to the English translator's practice who did not quote his sources and would sometimes abridge some passages, and because my cultural and introductory notes were many, I ended up with a bigger volume than foreseen and calculated by the Editor and the printer. So some of my footnotes were reduced into a glossary and some 26 translated stories, after a difficult choice, were kept for another volume.

However, I had succeeded in some important points: producing a faithful and elegant French translation as much as possible, from verified editorial sources, without any cutting of so called embarrassing passages, with a historical and literary introduction based on my Urdu reading (Manto, his critical views, his article about cinema, Urdu critics and comments by Urdu speaking critiques etc). But I had failed in my attempt to have at least one bilingual story (Urdu original text confronted with its French translation), the modern colour photograph illustrating the cover was the publisher's choice: it might have some aesthetic value but did not convey anything to the French speaking reader about Manto's favourite themes. A portrait of Manto was put in the second page, taken from so many editions of Manto, with his self composed Urdu epitaph, my translation of it being modified by the Publisher, like some other passages of my translations. And the sub-title of the volume said 'stories translated by Alain Désoulières from Urdu (Pakistan)' quite a misleading statement forgetting that Manto entire formative years and life, barring five years after Partition were spent in India.

To sum it up, even today a powerful publisher can arrange and even distort the work of the literary translator.

\section{About Illustration and Translation}

When literary translation was established as valuable creative writing and, at the same time, acknowledging the copyrights both from the author and the original publisher, in the late 19th century, as far as European languages were concerned, it became fashionable to illustrate translations of so called classical literature with beautiful sketches and engravings and even with water colours and also with artistic binding and illustrated covers. Printing was becoming a booming industry and readership was growing with small bourgeoisie and middle class having access to secondary education. Reading translations of classical literature like the Inferno by Dante Alighieri, Don Quixote by Cervantes or The Arabian Nights richly illustrated was becoming more and more fashionable and, out of those illustrated translations operas as well as stage dramas with artistic painted decors were often produced. Then 
the advent of cinema inspired by literary (first classical) fiction did boost literary (illustrated) translation because there was a growing demand for fiction from outside even oriental fiction (rather in a colonial fashion). But especially after the advent of talking cinema and sophisticated coloured films, a time came, in the 1950s when, except for the cover, translated literature was selling in cheap 'railway station bookshop' and pocket editions, especially novels translated from English into French.

In India, translation of Oriental and Indian 19th century literature (including Urdu and also Persian literature from India and Iran) into English was sometimes beautifully illustrated. And more so when adapting Indian literature into English for the European taste, with sketches and images often inspired by the Indian 18th century miniature tradition. Unfortunately when Persian or even European literature was translated or adapted into Urdu with a flourishing printing industry based on nastaliq calligraphy by lithography, illustration was totally missing. A notable exception are the Naval Kishore publications and translations with Urdu, Hindi, Sanskrit and Arabic as target languages.

\section{Naval Kishore's Translations and Illustrated Publications}

Munshi Naval Kishore (Lucknow 1836-1895) as a printer and publisher had an enormous production in the above quoted languages, with teams of translators and calligraphers, and a big printing press of his own. ${ }^{4}$ Here we shall confine our comments only to two major Urdu publications of his firm: the Amīr Hamza tale and his Hazār Dāstān (Arabian Nights). Indeed, between 1890 and 1896, the learned Indian publisher from Lucknow (erstwhile Lakhnau), Naval Kishore (the administrative, literati munshi title, was in his family since two generations) edited in his literary journal the extraordinary wanderings of Amir Hamza Arab/Persian chevalier or noble knight in everlasting fight against his king, wicked magicians and even dragons. Translated and adapted into Urdu, the Persian Amir Hamza tale became Tarjumā e Dastān e Amīr Hamzā Sāhib Qirān (Translation of the Story of Amīr Hamzā Lord of the World). In fact it seems that the single Persian volume became twenty volumes, fifty thousand pages of what we would call Urdu Heroic Fantasy by at least four authors. The whole thing being renamed Tilisam e hosh rubā or The Fascinating Magics, in other words, more than a translation it is an adaptation and a creative work, with illustrations ${ }^{5}$; we know that it was not the first Urdu 'expanded' translation of the Persian epic but it was unsurpassed in novelty with the greater ever additions. This fact is probably because the team of translators working for

\footnotetext{
${ }^{4}$ A recent and interesting biography of Munshi Naval Kishore was published in the Urdu newspaper 'Aziz ul Hind', Delhi special issue, Muhammad Wasi Siddique, January 2014 ${ }^{5}$ My own copy of Tarjumā e Dastān e Amīr Hamzā is incomplete and in a fragile condition and in spite of being advertised 'illustrated' was deprived of all illustrations when I bought it.
} 
Naval Kishore had a unique Indian printing press that could challenge the work of previous British owned printing presses (including missionary press).

Thus Tilisam e Hosh Rubā serials became a forerunner of Naval Kishore's lengthy edition and Urdu translation (partially from Arabic and Persian) of the Arabian Nights, a set of tales that the British author Richard Burton was retranslating from Arabic (and Urdu sources) after the French Antoine Galland had translated them from genuine Arabic manuscripts adding also a set of 'orphan tales' of his own (with the help of his Arab informer, Hannah Diyab, from Egypt) whose traditional sources were unavailable, for the Ladies of the royal Court of Versailles in 1705 and later. Naval Kishore's Urdu translation was titled (in Persian) Hazār Dāstān (A Thousand Tales). Here we have to insert the intricate story of the first translation of The Arabian Nights into French, modern Arabic and English (also in India).

\section{The Intricate Story of the First Translation of The Arabian Nights into French and Arabic}

In a 2012 Copenhagen Conference dedicated to the Arabian Nights, also called Alif Laila ['alf laila'], it was aptly asserted that (quoting Abubakr Chraibi and Peter Madsen, Copenhagen, 2012) ${ }^{6}$ :

'There is no doubt that this piece of literature is the outcome of medieval Islamic civilization, the richest and most influential in the literary sphere, in cinema and the arts. It is also in the field of the imaginary a symbol at an international level. It is perhaps first of all a fruitful cooperation between several languages, several cultures and several geographic areas encompassing the Occident as well as the Orient...'

Yet, after long and indeed difficult researches, it was proved beyond any doubt that the rediscovery of the Arabian Nights in the West, as a unique original written corpus, was due to the translation (and adaptation) of an 8th century Arab manuscript from Aleppo, that was itself a nice blend of Middle Persian and Arabic oral traditions, thus a new work of adaptation and translation.

A French translation of the 8th century Arabic book was the work of Antoine Galland, an 18th century French translator and adapter working for the King of France at the Court of Versailles, the original Arab book and manuscript was brought to him by his informer the Syrian Hannah Diyab. Antoine Galland started publishing his Contes Arabes (Arabian Nights) volumes in 1705 .

Then we had another transformation/adaptation of the Arabic tales, termed as Arabian Nights and Alif Laila (One thousand and One Night, in French Contes Arabes and later Les Mille et Une Nuits) when Antoine Galland included and adapted the Arabic book to the French taste of those days, but he soon understood that he had no sufficient material to satisfy the demand of the

\footnotetext{
${ }^{6}$ Refer to our bibliography, e. g. Abubakr Chraibi and Peter Madsen, and Désoulières, Copenhagen, 2012
} 
Court of Versailles (mainly the ladies of the nobility who read avidly this exotic literature). So he requested the Syrian informer to give him more Arabian Tales to translate and adapt, beside the Arabic, and a dozen new tales were told by the learned Syrian, Hannah Diyab, to the French oriental scholar, Antoine Galland, who chose eight of them and added them to his translation of the Nights, but naturally he did so in his own way. Some of those so called 'orphan tales' (because their original Arabic source text was never to be found) had a greater impact than the original Arabic tales on later adapters and translators (including Arabic and Urdu writers). Indeed such tales as Aladdin and the Magic Lamp, Ali Baba and the Forty thieves, Prince Ahmed and the Flying Horse, though not being part of the original corpus and greatly arranged by Galland from 18th century Hannah Diyab oral tradition and creative fiction work, were treated as genuine 8th century Arab tales, and included in the French collection. In the 19th century, they were retranslated almost everywhere and also richly illustrated with beautiful engravings by renowned artists.

Galland's work were soon re-translated into Arabic, and The Thousand and One Nights (1848) by Edward W. Lane Lane, Edward William (18011876), and his famous successor Richard Burton's translation Arabian Nights, a richly illustrated edition published in 1885, all included the French Syrian tales from Galland's work and Hannah Diyab's fabricated tales.

Those so called Orphan Tales also provided a fantastic source of inspiration for French, American, and Urdu/Hindi and also very early Bengali cinema (more than 26 adaptations by Bombai Studios, c. Désoulières 2012). Especially Ali Baba, and also Aladdin and the Magic Lamp, sometimes several fabula from those Orphan Tales were blended together as a single fiction.

But again it must be said that such a formidable success both in illustrated book form and on the silver screen as well as on the TV screen could have never been achieved without the equally great work of hundreds of translators (who would now go back to both original and French/Syrian sources) a work completed by learned script and lyrics writers and adapters.

Munshi Naval Kishore understood the necessary competition with the English Indian readership market and, very aptly, introduced sketches and drawings inserted in the Indian language text, using the same lithographic block both for image and text. And that was a great achievement: the initial cost was quickly absorbed by a subscription and distribution system all over India and even as far as London and Egypt. Indeed a very interesting example being his translation and adaptation of the Arabian Nights into Urdu (see illustration below) of the Ali Baba tale - by the way, a creation of Antoine Galland and Hannah Diyab, that was never part of the old Persian and Arab Eighth century AD tradition.

Around 1896 and immediately after the Tilisam e hosh rubā or the Fascinating Magics, Naval Kishore edited in his literary journal the four volumes of Urdu translations of the Arabian Nights, but he might have 18 
wanted to counter the British author Richard Burton who was retranslating from Arabic after the French Antoine Galland from manuscripts he had somehow collected (from 1885). Naval Kishore produced then the Hazār dāstān or Alif Laila that is with the Persian title One Thousand Tales and his Arabic title was also One Thousand Nights (Alif Laila) and neither 'One thousand tales and one' nor 'One thousand nights and one' (Alif laila wa laila). Several authors participated, but their exact sources are not known. In any case, it was a clear attempt not to be estranged from the Arabic and Persian literature, while he also benefitted from the latest Arabic edition that included the 'orphan tales'.

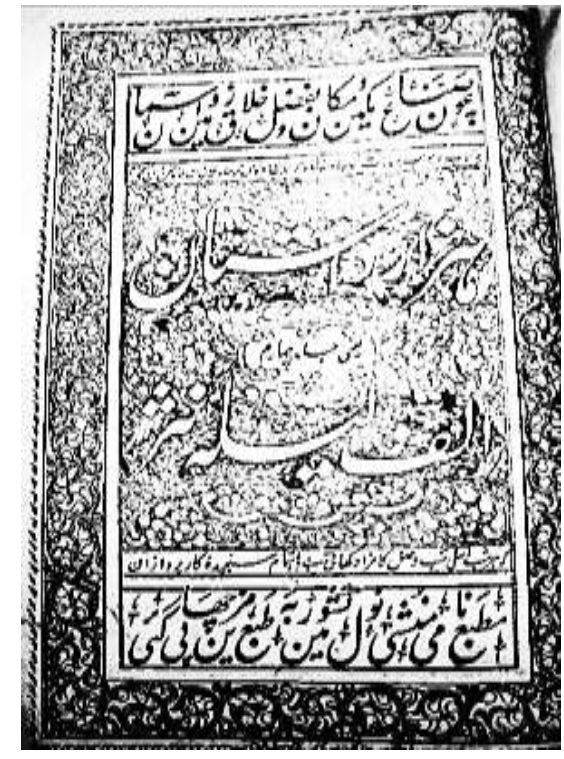

FIGURE 4. Ornamented and calligraphed cover of Hazār dāstān or Alif Laila (One Thousand Tales or One Thousand Nights) in Urdu, published by Naval Kishore, c. 1896 and well illustrated as a response to the colonial cultural alienation through English translations. $^{7}$

\section{A Note on the Illustration of Urdu Hazār dāstān}

Another important aspect is the novel way of illustrating those early printed Urdu Hazār dāstān / Alif Laila tales, introduced as traditional tales for adults. Indeed, printing in Urdu was not a typographic affair, but a simple reproduction by way of lithography of hand written literary works by copyists and calligraphs. That meant no rupture with the illuminated manuscripts tradition. Because of cultural identity reasons typographic printing, with Arabic naskh character (font) style, was never popular. Urdu typography was

\footnotetext{
7 Illustration is from my own collection, 19th Cent. printed book, Naval Kishore publication c.1896, Lucknow, fragile and yellowish paper.
} 
far from perfect, and mostly initiated by Christian missionaries and British colonial officers who did not favour the Indo Persian tradition. Lithography, primarily for newspapers, was cheaper than typography and allowed the survival of calligraphy. But unfortunately lithographic reproduction of literary texts would exclude illustration, for a simple economic reason: the copyist had to do a sober and regular work, save space and paper, to compete with typography and industrial printing. The only concession made to the rich Indo Persian illumination tradition would be for the book cover, and first pages where titles would be written in elaborated nastaliq calligraphy with some floral ornamentation (see reproduction above). The professional illustrator and painter (musawwir)who use to be richly retributed by the Indo-Persian Nabab or Prince, working hand in hand with a calligrapher for the illumination of a classical Persian novel like Amir Hamza had simply vanished with the fall of late Mughal or other Princely States. And the calligrapher was becoming a mere copyist.

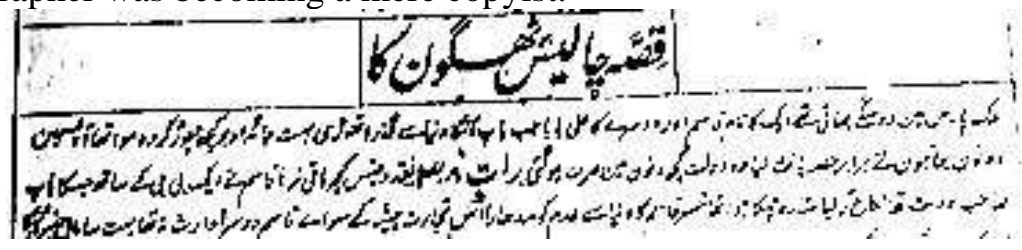

FIGURE 5. Title page of the Story of the Forty Thugs [thieves] Qissā călīs thagoñ $k \bar{a}$ In the second line we have the mentions rât 38 (Night number 38, out of the traditional numbering of the Arabian Nights) ${ }^{8}$

Perhaps the huge success of late 19th century illustrated editions of the Arabian Nights mostly translated from Galland and contemporary Arabic sources by British publishers, as big volumes with a luxury of full page engravings (sometimes clearly inspired from Indian miniatures and Mughal art), perhaps that challenged an astute Indian publisher such as Nawal Kishore to return to storytelling, and illustrated storytelling for that matter. The interesting thing is that it occurred barely a few years after the introduction of cinema fiction on Indian soil. Nawal Kishore had just launched an Urdu translation, and huge adaptation of the Persian medieval novel Amir Hamza, but without illustration. This time it was Hazār Dāstān yan̄ Alif Laila, ba tasvir, A thousand stories, that is Alif Laila, [but] illustrated. And a success story it was from very beginning with a reduced number of stories, contrary to the huge adaptation of Amir Hamza. At the same time English styled stage drama and even western inspired opera, had gained increasing favour among

\footnotetext{
${ }^{8}$ Source : my own copy, Vol. IV, pp. 16 and 17, the numbering of the Nights in the case of the orphan Ali Baba tale (a creation of Galland and Hannah Diyab) is a clear indication that the Naval Kishore team of translators, adaptors and illustrators used at least one recent Arabic version based on the French translation, perhaps in addition to more genuine Persian sources.
} 
the Bombay Indian rich class. And cinema exhibitions were already taking place within the theatres of Bombay owned by the Parsi élite of the town.

\section{The Illustrations of Ali Baba and the Forty Thieves in Naval Kishore's}

\section{Translation}

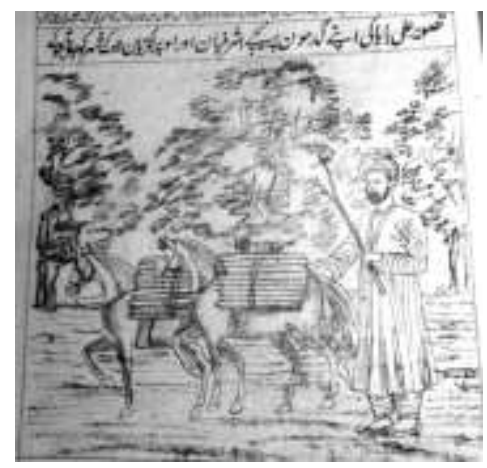

FIGURE 6. First Illustration and Text of the Ali Baba Tale

Taswīr Alī Bābā kī apne gadhoñ par nīche asrafiān aur upar

lakrīyān lād ke sahar ko jāte hu'e

(Image of Ali Baba returning to the town, on his donkeys are gold coins underneath the loads of fire wood).

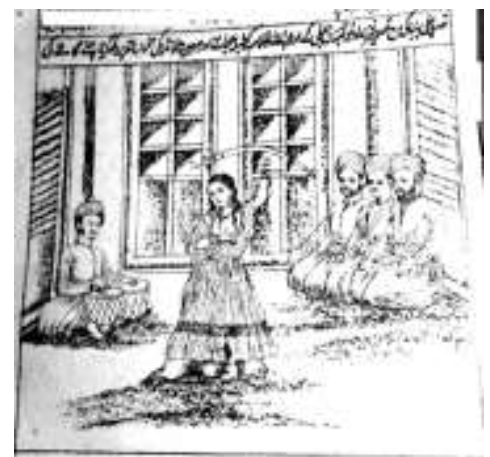

FIGURE 7. Second Illustration and Text of the Ali Baba Tale or the Story of the Forty Thugs:

Taswīr Alī Bābā kī, ma' taswīr farzand aur x(w)aja Hasan jālī ke aur Abdullah gulām tablā bajāne aur Marjinā laund̄i kī talwār hāth par rakh kar nācne gāne k̄̄

(Image of Ali Baba with his son and the fake Khwaja Hasan and the servant Abdullah playing the tablas and the slave girl Marjina holding a sabre on her hand and dancing and chanting) 
Figure 6 calls for a few comments: The wording of the title above the picture sticks to Galland's translation, but don't these donkeys look like two beautiful horses walking on a strict parallel pace? And Ali Baba's attires do not suggest a poor Persian wood cutter but rather a noble man from Lucknow. The artist seems to winkle at his (rich) readers.

Figure 7 also calls for similar comments: The wording of the title above the picture again sticks to Galland's translation, but the picture itself has another echo - we are in an Anglo Indian house with high and large windows and small wind panes, the three men sitting are just like the previous portrait of Ali Baba, rather noble men watching a raqqāsa (a dancing girl, bare foot with a traditional Lucknavi gharara dress, her veil drawn upon shoulders not hiding her chest) dancing and singing to the tune of an Indian musician sitting and playing a pair of tablas. The girl is holding a sabre (according to the story she is about to kill the leader of the forty thieves, the fake merchant) but this picture rather evokes a mujrā scene. A mujrā being a peculiar show with a courtesan dancing and singing with her musician(s), is quite a favourite show among the elite of the town or princely state. No doubt Naval Kishore's illustrator really wished to please the elite readers of those days, adapting the so called Arabian Nights to the taste of the day.

\section{About Audiovisual Adaptation of Literary Fiction}

Two key points to remember

1. For a long time, whether in India or in Europe, there was no clear boundary between adaptation and translation. In the French classical literary tradition, the notion of author, adapter and translator is rather hazy - the famous actor and playwright Molière translated and adapted freely from the Spanish and the Italian drama and even paid a French author/rhymer for his plays in verse, something his social status as an actor did not allow him to do. Similarly in Urdu, whether it would be fiction writing or historiography in late 18th and late 19th century respectively, often the author/translator would acknowledge his Persian, Arabic or even Sanskrit model, but would not hesitate in making a version of his own and even add creative writing of his own, while still retaining the pretence of the prestigious foreign or classical model. The author/translator would not hesitate in transforming a novel into a drama or vice versa. So adapting a literary text for the silver screen or for television was not really a new process.

2. Adaptation of a literary text for audiovisual translation requires first a careful translation and then specific dialogue writings. Later on, a secondary translation process is the subtitling, that can also be multilingual now (since a few years) with the advent of more sophisticated DVD. And of course the director's storyboard is an attempt to transpose/translate, for example, a novel into choices of décor and animated images. 


\section{Quoting Two Sets of Literary Tales Adapted to Cinema and Television}

(a) The Arabian Nights adapted to cinema and television (France and India)

(b) Maupassant's Tales and Stories adapted to cinema and television (France and India)

Both set of literary texts have been translated in many languages thus belonging to what may be termed as World Literature, and, consequently adapted to stage drama, cinema and televisions of so many countries. This relatively new phenomenon is a universal feature of literature, both classical and modern but being first spurred by the literary translation works that knows no boundaries. Conversely, the subsequent diffusion through DVD and now internet diffusion (which is apparently free) also boost the sales of both original and translated texts in the bookshops, but only for a short moment. Fashion in audiovisual production is unstable. However, both the Arabian Nights (Alif Laila according to the popular Indian TV concept) and Maupassant's Tales and Stories seem to have very long parallel careers as cinema and television adaptations both in India, France and Hollywood. Adaptations on the silver screen lasted for over a century and continue to happen for the Arabian Nights and over thirty years for television serials. (refer, to the author's own 2012 catalogue of Alif Laila inspired films.) ${ }^{9}$

The development of audiovisual adaptations of literary (often translated) texts generated two different literary activities (that are barely recognised as such but are of tremendous importance): the storyboard and decor writing on one side and the dialogue writing, keeping in view some cultural concessions or the director's need for original creative writing.

In addition, the DVD and digital versions markets are increasingly in need of subtitling, voice over and special subtitling for the deaf and hard of hearing, thus, generating another kind of translation and adaptation with a very limited text fitting the projected image and even colour codes for persons hard of hearing and fitting the mood of the characters on the screen.

To give a precise idea of the importance of translation and adaptation of literary tales, we provide an appendix with two lists of films adapted from the Arabian Nights (USA and India), and, in appendix 2 as an illustration the first page of Alif Laila (Bombay, 1953), a booklet of the film.

\footnotetext{
9 (21 11 2012) DÉSOULIÈRES, Alain, [From Hollywood to Bollywood One Thousand and One Arabian Nights, contribution to graphic exhibition and scientific paper in the IMA Exhibition Catalogue) Éd. Hazan Paris), c.14 p. plus illustration, and «cinéma indien et Mille et Une Nuits» c. 10 pages etc. format 230 x $310 \mathrm{~mm}$ (Extracts from my communication to Mille et Une Nuits Conference (Arabian Nights), Copenhagen University, 30 May 02 juin 2012)
} 


\section{Appendix 1}

List of Films as Adaptations of Translations of the Arabian Nights Tales

a. Hollywood studios (USA)

1924 The Thief of Bagdad, by Raoul Walsh with Douglas Fairbanks, silent, $\mathrm{B} \& \mathrm{~W}$.

1940 The Thief of Bagdad, remake, by Michael Powell, Ludwig Berger and Tim Whelan

1943 Ali Baba and the Forty Thieves, by Arthur Lubin,

1947 Sindbad the Sailor, by Richard Wallace, Douglas Fairbanks Jr.

1958 The Seventh Voyage of Sindbad, by Nathan Juran

1960 Ali Baba et les quarante voleurs/and the Forty Thieves, by Arthur

Lubin (Hollywood), remake franco-italian co-production

1963 Captain Sindbad, by Byron Askin, Technicolor,

1965 Sword of Ali Baba, by Virgin Vogel,

1973 The Golden Voyage of Sindbad, by Gordon Hessler

1977 Sindbad and the Eye of the Tiger, by Sam Wanamaker

1992 Aladin, cartoon film (Disney Film) remake in 2012, TV Disney

Animation in 1994 (from a French cartoon film, Aladdin, 1970, by Jean Image)

b. Bollywood studios (and other studios in India)

1896 Projection in Bombay stage drama theatre hall, of Frères Lumière

(Lumière Brothers, Lyon, France) films (including a short Ali Baba film $)^{10}$

1899 Hiralal Sen, 1899-1900, Ali Baba (théâtre filmé, Calcutta et Bombay)

1903 Hiralal Sen Ali Baba and the Forty Thieves, silent, B\&W.

1927 Ali Baba and fourty thieves, B.P. Misra, silent, B\&W.

1927 Arabian Nights/Alif Laila, Madan Theatres, silent, B\&W.

1932 Ali Baba, Madan Theatres

1930 Sher-e-Arab (Arabian Nights, The Tiger of Arabia), silent

1930 Hatim Tai, de Prafulla Ghosh et Krishna Films, silent

1933 Aladdin, Madan Theatres

1933 Arabian Nights (Alif Laila) par Balwant Bhatt (Bombay Talkies)

1940 Arabian Nights (Alif Laila) by Niren Lahiri

1946 Sher-e-Baghdad (The Tiger of Baghdad) by Homi Wadia

1953 Alif Laila, par Amarnath

1955 Sindbad, Ali Baba Aladin P. N. Arora

1958 Sim Sim Marjina (Sesame Morgiana, Ali Baba) by Naren Dave

\footnotetext{
${ }^{10} \mathrm{We}$ cannot afford to insert a list of French and French language films, cartoons and even stage shows adapted from translations of Arabian Tales (Contes Arabes) by Antoine Galland, from 1896 to 2017 (with a recent animated cartoon), as it would more than double this annexe.
} 
1958 Sindbad ki beti (The Daughter of Sindbad) de Ratilal

1967 Arabian Nights (Alif Laila) par Nanabhai Bhatt

1980 Ali Baba Chalis Chor (Ali Baba and the Forty Thieves) par Umesh

Mehra et L. Faiziev (India and URSS)

1992 to 1995 Alif Laila TV serials by Ramanand Sagar et al. Arabian

Nights (Alif Laila) par Balwant Bhatt, en 1933 (Bombay Talkies)

2009 Aladin by Sujoy Ghosh, with Amitab Bacchan, Jacqueline

Fernandez, Sahil Khan, Riteish Deshmukh, (with recent DVD edition).

\section{Appendix 2}

\section{"ALIF LAILA"}

The Story of "Alif Laila" takes us back to such remote times that even the filght of fancy is hampered in its revival. There is no incident that is old if one regards it with a deeper petspective: no story that does not reappear in all its vileness of beasty among the race of man. After his birth a man is only a man but those about him choose to call him by different names and the partition of earth destroys whatever lintle of sympathy and kindness that exists in him. But human nature bas remained steadfast and niether the bar.its of relegion nor the bamiers of land have sacceeded in changing it. In every relegion in every race, every man has brought darkness threogh his evil and light throogh his goodness.

Love raises man to beavens if it is true and love if it is false casts him into the gutter. The story of "Alif Laila" depicts the struggle that takes place between love and lust and bow love triumphs over lutt.

Alladin a poor wcodeutter is deeply in love with the pincess Diluram the prakies of whose beaaty and grace he sings forever thrcugh the streets of Baghded. Niether lis uncle's beatings ncr his own f.iend Rashid's remenstrances stcceed in making him abandon the love that ke fee's for ber. A magician called Afrasiab is alio bent upon extinguishing the fires of bis lust with the ccol betuly of the princess's charms and by employing his magical instrunent he ccunes to know that Allacin is the very person through whem he can obtain the gratification of his evil desies. On the one side there is the couraçe and love of Alladin and on the ether the vicicus desires of the Magictan. The magicis $n$ is stiving to axhieve the lamp which will increase his own diatolic fowers for the maricisn krows that he enchanting lamp contains a werman in the fom of Geti who hes been captured thourands of years before by the Kings of Geni, Baknatoth. The magician alto knows that not oniy a matchless beauty but also a pure heart is enclosed in the wonderful $\mathrm{k} m$ ? and for this teason he wants to make the princess Dileram the prey of his evil desires. The effects of the pincess's beauty on the heart of Alladin is so rood that it has changed it into a sacred place. Time does not in the beginning bcl, the good or rather it puis them on trial and thore who emerge successful fiom these trials are the ones who. receive their hearts desires.

Life can be called by another name 'sraggle' and it is every mun's desire to ceme out tritmphant threush this struggle and bow Alladin dees this is worth seeing on the screen.

Alif Laila Film Booklet, p.1 Bombay studios 1953, source: author's personal collections 


\section{Reference}

DÉSOUlières, AlAIN. 1998. 'Marginality and Anti-heroes in South Asian Media Themes.In panel 31, Literature, Theo Damsteegt, Leyde, and Désoulières Prague, European Conference on Modern South Asian Studies, 15 pp. communication doc.

DÉSOUlières, AlAIN. 2011. Circulation and Adaptation of Arabian Nights Tales in Urdu, from 18th Century Masnavi to Indian Cinema, 21st Cent. La circulation des contes et l'adaptation des Mille et Une Nuits en ourdou, du Masnavi (XVIIIe s.) au cinéma indien (XXIs.), pp. 214 à 243, Cairo University Nov. 2010, Conference Proceedings, Dar El Nashir, Cairo.

DÉSOUlières, AlAIN. 2012. From Hollywood to Bollywood One Thousand and One Arabian Nights, contribution to graphic exhibition and scientific paper in the IMA Exhibition Catalogue, illustations. IMA and Éd. Hazan Paris), (Extracts from my communication to Mille et Une Nuits/Arabian Nights Conference, Copenhagen University, 30 mai 02 juin 2012).

DÉSOUlières, AlAIN. 2010. Cultural Competence in Urdu an overview of a TV serial Drama by K. A. Rizvi, 25 p. La compétence culturelle en ourdou, aperçu d'une dramatique de K. A. Rizwi, 25 p. in "Implicites, Stéréotypes, Imaginaires", la composante culturelle en langue étrangère, Direction George Alao, Héba Medhat-Lecocq, Soyoung Yung Roger et Thomas Szende, (Plidam, Inalco) Éditions Archives Contemporaines, juin 2010, Paris, 201.

DÉSOULIÈRES, ALAIN. 2014. Teaching Language and Literature with Indian/French TV Drama, inspired by Maupassant, The Sixth CLS International Conference CLaSIC 2014, Knowledge, Skills and Competencies in Foreign Language Education, National University of Singapore (NUS with Plidam, Inalco Paris), 4-6 Dec. Book of Abstracts, NUS.

DÉSOUlières, AlAIN. 2017. Littérature et Cinéma, et Séries Télévisées / Literature and cinema, and television series, Practice and didactics, short paper and Presentation in French : L'enseignement de la Littérature et l'audio-visuel (ourdou, français) Colloque international sur la Didactique, 6 avril 2017, Teaching of Literature and Audio-visual, a presentation, JNU, School of Language, CFFS, New Delhi, International Conference on Didactics, New Delhi.

Yves ChEVREL, ANNIE COINTRE ET YeN- MAÏ TRAN-GERVAT. (EDS.) 2014. Collectif : Histoire des Traductions en Langue Française, XVIIe et XVIIIe siècles, collectif, coordination Yves Chevrel et Jean-Yves Masson, sous la direction d'Yves Chevrel, Annie Cointre et Yen- Maï Tran-Gervat, Ed. Verdier, Paris, 1573 p. voir aussi dans la même série : Histoire des Traductions en Langue Française, XIXe s. et XXe s. 2014 et 2016. 
GUIDÈRE, MATHIEU. 2013. Introduction à la traductologie, penser la traduction, hier, aujourd'hui, demain, coll. Traducto, Bruxelles, De Boek Université, 2e édition, 2013 Bardet, G. et Caron, D. Littérature et langages de l'image, enseignements d'exploration et objets d'études, Paris, Ellipses.

MuHAMMAD, WASI SIDDIQUE. 2014. Mashriqi ulūm aur funūm ke muhāfiz, Munshi Naval Kishore [A gardian of Oriental learning and arts, Munshi Naval Kishore], in 'Aziz ul Hind (Urdu Newspaper) s pecial Edition, New Delhi. 